\title{
Understanding Social Resistance to the Ebola Response in the Forest Region of the Republic of Guinea: An Anthropological Perspective
}

\author{
James Fairhead
}

\begin{abstract}
Why did Ebola response initiatives in the Upper Guinea Forest Region regularly encounter resistance, occasionally violent? Extending existing explanations concerning local and humanitarian "culture" and "structural violence," and drawing on previous anthropological fieldwork and historical and documentary research, this article argues that Ebola disrupted four intersecting but precarious social accommodations that had hitherto enabled radically different and massively unequal worlds to coexist. The disease and the humanitarian response unsettled social accommodations that had become established between existing burial practices and hospital medicine, local political structures and external political subjection, mining interests and communities, and those suspected of "sorcery" and those suspicious of them.
\end{abstract}

Résumé: Pourquoi les initiatives de réponse contre l'Ebola dans la région supérieure de la forêt de Guinée ont rencontré des résistances régulières parfois violentes? Élaborant sur des explications existantes en matière de "culture" et de "violence structurelle" locale et humanitaire et en s'appuyant de même sur des recherches précédentes anthropologique sur le terrain ainsi que sur de la

African Studies Review, Volume 59, Number 3 (December 2016), pp. 7-31

James Fairhead is a professor of social anthropology at the University of Sussex. He is the co-author of Misreading the African Landscape: Society and Ecology in a Forest-Savanna Mosaic (Cambridge University Press, 1996), Vaccine Anxieties: Global Science, Child Health and Society (Routledge, 2007), and African-American Exploration in West Africa: Four Nineteenth-Century Diaries (Indiana University Press, 2003). His research focuses on the history of the Republic of Guinea and issues related to the environment, medical research and infant health, and conflict. He was a member of the Ebola Response Anthropology Platform, which provided social analysis in support of the health and humanitarian response to the Ebola epidemic. E-mail: j.r.fairhead@sussex.ac.uk 
recherche historique et documentaire, cet article soutient que l'Ebola a perturbé quatre accommodations sociales précaires qui avaient permis jusqu'ici à des mondes radicalement différents et fortement inégalitaires de coexister. La maladie et la réponse humanitaire ont déstabilisé les accommodations sociales qui s'étaient établies entre les pratiques funéraires existante et la médecine hospitalière, les structures politiques locales et l'assujettissement politique externe, les intérêts miniers et les communautés et enfin entre ceux suspectés de "sorcellerie" et ceux qui les suspecte.

Keywords: Ebola; Guinea; violence; resistance; funerals; party politics; mining; sorcery

By October 2014, as the Ebola crisis escalated in the Forest Region of the Republic of Guinea and catastrophic scenarios seemed possible, global attention turned to burial practices in the region. Those who were familiar with Ebola from past "outbreaks" knew that the Ebolavirus is most infective in the two or three days immediately before and after a person's death and that control over the epidemic requires addressing matters of care and mortuary practices (Hewlett \& Hewlett 2008; Epelboin et al. 2008). Contact data from patients during this epidemic was beginning to show that 60 percent or more of infections could be attributable directly to participation in care or mortuary rites and thus that the epidemic could be stopped if the social practices surrounding care and death could be conducted safely (WHO 2014b).

The public health logic was clear: the ill should be isolated within Ebola Treatment Centres (ETCs) and burials should be made safe. Yet this message was not heeded by all, and for many reasons. Symptoms of Ebola were often hard to distinguish from many other ailments, and people delayed traveling to ETCs until it was too late. News that Ebola was deadly and had no cure did not make Ebola Treatment Centres attractive, and travel was difficult to arrange and costly in any case. Families worried that children and others would not survive the quarantine that would be imposed on any family in which the virus had been identified. And misinformation that Ebola was caught from bushmeat provided false confidence to those who didn't hunt or eat it (Richards et al. 2015a).

Yet in southeast Guinea, the issues were not just those of noncompliance but also of resistance-often violent resistance-to health interventions. Médecins Sans Frontières (MSF) constructed the first ETC in Macenta within days of Ebola's being formally identified, but only a week afterward, on April 4, 2014, urban youth attacked it and threatened the fifty or more new expatriates, arguing that the threat of Ebola was "false" or that Ebola was being spread by outsiders (L'Obs 2014). In June and July 2014 twentysix Kissi-speaking villages in Guéckedou Prefecture isolated themselves from the Ebola response, cutting bridges and felling trees to prevent vehicle access and stoning intruding vehicles (Anoko 2014a). According to the anthropologist Julienne Anoko, more conciliatory villagers were accused of being traitors, and those assisting NGOs were beaten. In several instances 
mortal violence was only narrowly averted. A social mobilization team that ignored a woman's warning at the entrance to Sagbè village only narrowly escaped. In mid-June a delegation was assaulted and wounded (Anoko 2014a). In the Kissi village of Tekoulo, youth isolated themselves in farm camps in self-imposed quarantine, worried that elders or humanitarian teams would bring the virus (Fassassi 2014). "We don't want any visitors. . . We don't want any contact with anyone," they said, referring to MSF. "Wherever those people have passed, the communities have been hit by illness" (quoted in Nossiter 2014a).

In August 2014 Toma-speaking villagers in Koyama (Macenta Prefecture) took hostages and torched vehicles and a health center (Claver 2014). Twenty-two people were wounded in a riot in Nzerekore city that was triggered when public health officials sprayed disinfectant in its massive market (GuinéeConakry.info 2014). On September 16, eight members of a high-level educational delegation of doctors, politicians, and journalists were murdered in the administrative "sous-prefecture" headquarters of Womey. Their bodies were disposed of in a latrine, and the survivors were pursued (Ouendeno 2014). In the following months many villages in the vicinity isolated themselves (Nossiter 2014b). Everyday forms of resistance were more generalized: an average of ten attacks per month was reported against Red Cross volunteers in Guinea in the last six months of 2014, ranging from verbal to physical assaults (ICRC 2015).

This reception hampered the response early in the epidemic and therefore enabled it to gain a grip in the region. Understanding such a social response is thus a key public health issue. This focus on "resistance" should not occlude attention to the widespread cooperation that also existed, especially as the epidemic unfolded. While resistance was much more frequent and violent in Guinea than in neighboring Sierra Leone and Liberia (ACAPS 2015; Pas 2015), there was still much cooperation as well. ${ }^{1}$ Yet probing the nature of this resistance can shed light not only on the spread of the epidemic, but also on conditions and policies that encourage community cooperation.

Two explanatory discourses have dominated the debate over the apparent continuation of existing mortuary practices and resistance to humanitarian intervention-one broadly cultural, the other focused on structural violence. Initially, as Benton and Dionne note, when the significance of so-called "super spreader" funeral events became clear (major funerals at which dozens would be infected), "initial international media coverage . . . focused largely on the cultural practices that heightened risk for contracting and transmitting the disease" (2015:224). Attention was focused on the initiation societies and the mortuary practices they conducted, such as touching or sleeping alongside the body; on divinatory practices using body parts to identify sorcerers; and on clandestine exhumations and reburials. Cultural explanations fueled sensational news coverage that "contributed to fears of Africa as a disease-ridden continent and to the dehumanization of Africans navigating the epidemic" (Benton \& Dionne 2015:223). ${ }^{2}$ 
Indeed, even within Guinea, these discourses stigmatized Ebola as a disease of the "forest people" as opposed to Guinea's other ethnicities and of their religious complex as opposed to Islam or Christianity - a stigma which itself helped Ebola travel (Camara \& Lazuta 2015).

Early in Africa's HIV and AIDS epidemic, "cultural" explanations for its spread had focused on the sexual practices that shaped the way the epidemic unfolded. At the time, critics of this approach argued that such a "cultural" explanation eclipsed attention to the more material conditions of structural violence (poverty, politico-economic and gender inequalities) that shaped both sexual conduct and inadequate health provision (Farmer 2004). In the context of the Ebola crisis, such a critique again seemed pertinent as attention to "exotic cultural practices" obscured the "larger political economic context shaping the likelihood of a major disease outbreak and the ability of relevant actors to respond (Benton \& Dionne 2015:224)."3

In efforts to de-exoticize the discourse, several works highlighted how "common sense," rather than "cultured sense," drove social responses to the disease: the fact that Guineans avoided ETCs and ambulances for the same reasons we all would do so-for fear of cross-infection-and that villages and city districts isolated themselves for the same reasons that public health officials establish lockdowns-for the sake of quarantine. As Faye (2015) points out, practical reasons for noncompliance were falsely construed as "resistance," while actual resistance had practical logics. In several circumstances, explanations in terms of "culture" were overplayed, and such "othering" of communities detracted from attention to more obviously shared goals and strategies.

For some taking this line, an overarching intent was to recover respectto enable public health officials to engage with communities more respectfully. And yet there is a problem: this critique suggests that respect is to be achieved through appeal to our common nature, rather than a respect for difference. Moreover, such an approach silences how the worries about ETCs and ambulances were not just about quarantine or cross infection. As we shall see, people were worried about ETCs stealing blood and body parts, and ambulances were blocked for fear that they had come to infect people intentionally.

In short, while there are problems in invoking cultural explanations, there are also problems suppressing them. Explanations drawing on our "common human nature" actually universalize "Western common sense" as "human nature," silencing local framing-locally specific sense-making. While overlooking alterity might be tactically appealing, doing so can be even more demeaning.

This is all the more relevant in this region, as a dominant theme in recent anthropological writings concerning it has been to understand how cultural practices and local sense-making have been shaped by centuries of structural violence. Classic works such as Shaw's Memories of the Slave Trade (2002) reveal how slavery, colonization, and globalization left a legacy in 
transformed religious practices and existential fears. ${ }^{4}$ Works on political culture and the place of initiation societies in it, such as those by McGovern (2013), Højbjerg (2007), and Ferme (2001), do the same. From this perspective, attention to structural violence actually renders attention to cultural aspects more, not less, relevant. In suppressing cultural readings, then, are we in effect suppressing the significance of radically different experiences of structural violence?

If there is something of an impasse here, it is one of anthropology's own making: a situation in which discussion of things "cultural" tends to slip into more totalizing ideas of "culture"-of there being a Kissi "culture," or indeed, its symmetrical opposite, a "humanitarian culture" or a "Western culture." 5 Anthropologists have great difficulty in handling the existence of "radical difference" in what are so obviously interpenetrating (multicultural, hybrid, transnational, creolized, globalized) worlds. ${ }^{6}$

To begin to address this impasse, however, I can observe that to speak of Kissi-speaking people in terms of a totalizing "Kissi culture" would in fact be antithetical to the incorporative sociality in this region-a region that welcomes strangers; where people consult health practitioners from a huge diversity of therapeutic traditions (biomedical, herbal, ancestral, Islamicwhatever works or might work); whose young try out new churches and sects, travel far and wide, attend university, and work for the national police or the army, or seek employment and fortune in the mines and cities of Guinea and beyond. During extended anthropological research in a Kissi village in the southeast of Kissidougou prefecture between 1992 and 1994, and again in 1999 and 2001, I encountered reasonableness, not exclusionary rationality; practical eclecticism rather than "ontological" intolerance. Thus villagers put up with much that they frown upon: for example, accommodating the less-than-generous traders from other regions who live in their villages because, among other reasons, they often rely on them for loans. And while some people attend church and visit hospitals, this does not mean that health and existential anxieties associated with offending the land spirit or ancestors are no longer important.

This article attempts to look at the Ebola crisis in the Forest Region of Guinea through the lens of "social accommodation"-that is, the established norms of cooperation and coexistence that were violated throughout this period. What is meant by "social accommodation" will become clearer below: suffice it to say initially that the lens of accommodation foregrounds pragmatics in helping us understand why logically inconsistent practices do not displace one another. ${ }^{7}$ What I ultimately want to show, however, is that the unfolding events in the Ebola outbreak pushed even the limits of existing accommodations. "Red lines" were transgressed. Thus the article asks: what caused existing accommodations to break down? What events early on in the Ebola response breached the limits of reasonableness? What were the issues that united the communities? As the article will show, at least four kinds of local accommodations broke down-accommodations with hospital practices; accommodations 
with mines (and extractive economies); accommodations with state authority; and accommodations with sorcerers.

\section{Accommodations between Funerals and Hospitals}

Inhabitants of Gueckedou and Kissidougou Prefectures in the Forest Region of Guinea (Forestiers) have long been used to visiting the health posts, maternity clinics, pharmacies, medicine-merchants, and hospitals as part of the larger therapeutic landscape that embraces a variety of healing traditions. Given this plethora of possibilities, local residents do not make strong distinctions between "biomedical" and "traditional" health practices. In fact, other therapeutic distinctions that crosscut the biomedical/traditional divide are equally relevant to them: for example, the difference between specialists who treat familiar ailments and those who treat unfamiliar ones; health care providers who treat predominantly men or women; or those who require upfront compensation or allow for deferred payment. One cannot argue, then, that "biomedicine" and "Kissi culture" are somehow distinct and opposed (Leach et al. 2008).

While the logics behind biomedical practice and some Kissi health and mortuary practices could not be more divergent, as we shall see, they have not been incompatible as practiced. In particular, when relatives bring patients to Guinean hospitals, they find that the hospital layout and routines facilitate the expectation that routine caretaking-cooking, feeding, and doing the laundry-will be done by the family. Relatives can do all that they should for the family member, and even critically ill patients can receive visits from those who seek to pay their respects and register the dying person's last wishes. If the patient dies, his or her body is returned to the community so that the family can perform mortuary rites. Thus, as the biomedical order encounters the Kissi order in hospitals, modes of practical coexistence have emerged in which any cultural (or ontological) incompatibilities are not relevant.

Part of the global success of biomedical health systems lies in precisely this kind of accommodation: in the development of practices that respect and interfere minimally with cultural difference. Only in rather rare instances is this accommodation broken. In the U.K. and U.S., for example, blood transfusions, to Jehovah's Witnesses, are a "red line" issue (Jehovah's Witnesses n.d.). Jehovah's Witnesses do not usually avoid hospitals altogether, but, for example, they will refuse a blood transfusion for a child on religious grounds. In such cases the hospital sometimes attempts to exert authority, and the intense moral dilemmas and highly emotional responses connected to these resistances have intrigued the public and attracted the attention of journalists and novelists (see, e.g., McEwan 2014). Such moments are rare instances that render visible just how different we can be-the radically different realities we inhabit-and they probe our tolerance of one another. Importantly, such difference is usually hidden through many varieties of practical "accommodations." 
Within days of Ebola being identified in March 2014, MSF had opened an ETC in Macenta town. Yet within a week it was attacked by an angry crowd. There were two immediate flashpoints. First, in total contrast to the procedures followed by Guinea's hospitals (and to local expectations), there had been little, if any, attention paid to visitors in the hasty construction of the ETC to a standard, imported design. Second, bodies were either not being released to the care of their families, or they were returned unwashed and in zipped-up body bags to be buried by the Guinean Red Cross. These two practices ensured that essential modes of accommodation between the biomedical and local orders were likely to break down.

To understand just how sensitive this situation was, we need to consider not only the expected behavior of health care professionals, but also how death is envisaged and managed in the region and the significance of funerals for the living. My colleague Melissa Leach and I have lived and conducted research in villages in South East Guinea on and off since 1992 (e.g., Fairhead \& Leach 1996). Deaths, of course, are a regular occurrence, and on many occasions our routines, like those we lived among, were disrupted by it. However, the responses of the villagers, as well as what they expected of us, were various, and (at least to us) somewhat unpredictable. A very kind and jovial man had been delegated by village elders to "manage" us during our visit, and we were hugely dependent on our "minder" to help navigate our proper conduct through these somewhat baffling occasions. Only with time did we gradually discern something of their logic, helped through conversations and prompted by earlier research in the region, especially that of the French anthropologist Denise Paulme in the 1940 s $(1950 ; 1954)$.

In some cases, burials could be perfunctory. On one occasion a respected man died during the build-up to a major village celebration-the coming-out ceremony of Toma, the men's initiation society. This event was expected to attract visitors from far and wide, and I was slightly surprised to find that within an hour of the announcement of the death, the body had been buried next to his house, with funeral rites to be conducted later. On another occasion, by contrast, following a woman's death, all the men of the village (and we, as visitors) had to leave the space of the village entirely. We spent the day in a neighboring hamlet while the women's initiation society (Toma Vanlandua) organized and conducted the mortuary rites. On yet another occasion, we were beckoned to a neighboring village to "greet" a family who had experienced a most calamitous death-that of a pregnant women. By "greeting," one visits the bereaved family to acknowledge the loss, speak a few words of sympathy and respect, and usually offer a small banknote or two as a token gesture. But then on another occasion, after the death of a young child, we were beckoned to the family's hut only to be met by our "minder" who explained that it would be wrong to formally "greet" this as a death; our sadness would be fine, but not the gesture of money, as this was the "first death" experienced by these parents. On another occasion, on returning to the village after a few weeks away, we learned of the 
death of a man who had been particularly helpful to us in taking us to his fields and discussing his farming. And yet we found that we were neither to mourn him nor greet his family, since he had been identified after his death as having been a sorcerer.

There are some guiding principles that applied to all of these examples. First, most people hope that at death they will be born back into a parallel "village of the dead" where they will be reunited with those who had predeceased them-and also that they will retain links with the living. Living relatives conduct rites to encourage this result, because there is nothing more problematic for the living than an aggrieved ancestor, or one who has been unable to pass to this other world. Cherished relatives are buried in the village, and even a relative who is buried elsewhere can be brought home in the form of an object (often an antique iron bar) that was placed in and then removed from the actual tomb. Care is needed, however, to ensure that those who might bring ill fortune to the living are buried elsewhere and not returned to the village in any way. Sorcerers cannot be sent back to this parallel village, where they might continue their evil. Suspicions that a dead person was a sorcerer need to be investigated prior to their burial, and there are modes of autopsy that ascertain this. Nor is it acceptable to reintroduce into this village of the dead those whose "bad" death (for example by lightning strike) call their good character into question, or to do so for strangers whose character is unknown.

There is, however, a second set of principles that influences burials, which concerns relations with the natural order of things regulated by the land spirit. People can commit social faults that go "against nature" and have consequences not only for the person but for the wider world. Such faults, collectively known as maa, upset the orderly, healthy world in which people, crops, domestic animals, and wild animals reproduce and prosper. All these living entities need to reproduce in their correct but separate places: people in villages, crops in fields, and animals in the bush. They also should reproduce in their correct cycles. The seeds of one year's crop need to be kept separate from the seeds of the next. Similarly, married women and new mothers take steps (e.g., through controlled breastfeeding) to ensure that the reproductive cycle resulting in one child remains separate from the reproductive cycle leading to the next. Any action that confuses this orderliness can disrupt the wider world. Of significance here is that a death in one generation should not be confused with a death in the next. Therefore, it would be a terrible "fault" ( $\mathrm{maa}$ ) if a pregnant mother were buried with her fetus. Indeed, this is doubly problematic as with such a load (and bearing this fault) she would never make it to the village of the dead either (Paulme 1950,1954; Anoko 2014c). The fetus must be buried separately, or the burial would become a threat to all reproductive women and indeed, to the wider reproductive order on which people depend.

That the first child to die of any couple is buried according to special procedures also concerns relations with the land spirit, as this burial establishes a relation with it—and a way to intercede. Such a child does not so 
much "die" as "return," and he or she is buried in a special location at the edge of the village, wrapped only in the leaves of the medicinal plant Newbouldia laevis. As these are not deaths, they are not "greeted," nor will their relatives make the regular offerings that they otherwise do to dead relatives on family altars. If, on the other hand, there is a generalized problem-fire, drought - a diviner may indicate that offerings to these "first dead" must be made, as they are the ones best placed to intercede with the land spirit (i.e., with the natural order) that must have been perturbed by faults, and thus in a position to put things right.

In short, mortuary practices are not simply concerned with the disposal of a body. They are fundamental to the future of the deceased, their relatives, the wider community, and the environment. So when ETCs sought to exert control over the dead body, they were intruding into this most fundamental arena of social practice and anxiety. Not only did ETCs prevent people from caring for the mortally ill and witnessing the expression of their last wishes, but they also undermined the rituals of mourning, the settling of debts, the conducting of autopsy to identify the cause of death, the appropriate practices that help lead the dead to their appropriate destination (washing, oiling, dressing, closing eyes, preparing hair), the choice of burial location, and sacrifices. Moreover, as the specifics of burial of initiated adults involve their co-initiates-men for a man and women for a woman-the intervention of the ETCs undermined the work of the initiation institutions, too.

The significance of this rupture in the accommodation between the hospital and funeral practices was rendered visible early in the epidemic following the death of a pregnant woman by suspected Ebola in Gueckedou Hospital in June 2014, as documented by Julienne Anoko (2014c). The deceased's husband, brother, and mother refused to let the hospital bury the body, and sought to retrieve it and organize a caesarean so the mother and fetus could be separated before burial. Their aim was perhaps also to conduct an autopsy on the mother to check if she was a sorcerer, but mostly they intended to bury her separately so that she could make it to the parallel realm. They also needed to conduct certain rites to avert the generalized malediction that would otherwise follow for other pregnant women and the region; all women of reproductive age in the nearby villages had already fled to avoid this fate. Their families and the village authorities were cajoling the deceased's family to arrange the ceremonies as soon as possible to put the disturbed "order of things" back on track.

Yet the hospital refused to release the body due to the risks of contamination. In response, the family refused to establish a list of contacts to be traced, even though the case was linked to a chain of transmission. There was a stand-off for several days as the body decomposed. Anoko contacted senior leaders of the initiation society to seek alternatives, and eventually ways of cleansing the village and seeking the pardon of ancestors were identified to enable the pregnant women to be buried with her fetus. This was negotiated despite the continued concerns of many women and youth. 
The body was buried-though not by the Guinean Red Cross teams, which refused to handle it for fear, too, of the disrupted order of things affecting them-and a specialist was found living 50 kilometers away who could conduct the rite. The family and village authorities asked the WHO to pay (which they did, at U.S.\$650), and in exchange the family agreed to develop the contact list. ${ }^{8}$

This event was entirely exceptional, but it exemplifies the breakdown in the accommodation with the hospitals that Ebola precipitated. MSF maintained what it thought was usual "hospital" practice, claiming that "We deal with the living. The dead-it is the work of the Guinea Red Cross" (Le Marcis 2015). But this answer simply deflected responsibility rather than resolving the fundamental problem. The burial teams working for the Guinean Red Cross-themselves chronically underresourced, as Le Marcis documents-became the focus of resentment, threats, and violent resistance. Early in the epidemic these teams took bodies in body bags back to villages, overseeing their safe, chlorinated burial. As the epidemic escalated they buried the dead in unmarked graves in Guekedou's ETC cemetery. When this was full after six months, a new cemetery was established on the site of a waste landfill.

As the episodes above illustrate, the problems between the ETCs and the local communities were not a matter of mistrust of the ETCs. Rather, the modes of hospital visiting that were permitted and the treatment of the dead were "wrong" in a fundamental sense, and they required reparation. The conflicts also involved more than a clash of cultures. They were also connected to local institutional politics, which we now consider.

\section{The Political Accommodation}

A second dimension to resistance in Guinea's Forest Region concerned accommodations between communities and political authorities. Political authority in Guinea, dating back to French times, has a large element of direct rule, in which the party in power installs "outsiders" in regional, prefectural, sous-prefectural, and often district administrative posts. Guineans generally experience these intrusive representatives of state power as self-serving rather than benevolent, although they generally arrive at pragmatic accommodations with these imposed authorities. But with the arrival of Ebola-and, I will argue, of the financial and material flows it permitted-this accommodation was upset as political authority was bolstered by the humanitarian biopower associated with Ebola and the "difficult outsiders," in turn, came to be perceived as "the enemy." To understand the complex dynamics at work here, one needs to appreciate the difficult experiences of local citizens in relation to both the Manding (often Islamic) world to the north, and to the "white" (often Christian) colonial and neocolonial order. ${ }^{9}$

From the fourteenth century, those inhabiting what became known as the Forest Region suffered periodic conquest, during which territory 
was lost and people were enslaved. When this region was incorporated into Euro-American trade networks from the fifteenth century, slavery was intensified. Then the region was conquered militarily and colonized by the French. Both slavery and colonization were experienced as an encounter not simply with the Euro-American world, but also with Manding warlords who profited first from the slave trade and then from the rivalry between colonial powers. This brought terrible conflict and significant depopulation to the region into the early twentieth century (see, e.g., Fairhead \& Leach 1994) and heightened antagonism between inhabitants of the forest region and both the colonial (Christian) world and the Manding and increasingly Muslim political orders entangled with it (Anoko 2014a; Iffono 2010, 2011; McGovern 2013; Højbjerg 2007). The initiation societies that coordinate the cycle of life and prosperity, regulating trade routes, markets, and monetary value as well as organizing funerals, also orchestrated political relations of defense, solidarity, and confederacy. Initiation societies drilled initiates in the military arts of protection, concealment, defense, and battle, and trained them in their secret drum-based communication.

As McGovern (2013) and Højbjerg (2007) make clear, subsequent history has kept the same social and political cleavages alive. The Marxist revolutionary movement that won Guinea's independence in 1958 followed an aggressive policy of "demystification" against initiation societies, destroying their ritual objects, exposing secrets, and banning ceremonies in the pursuit of national unity, "modernity," and African communism (McGovern 2013). To inhabitants of the Forest Region, however-as well as to its initiation societies - this was experienced as political subordination to the Manding and Islamic north (to Malinke, Konyanke, and Toma-Mania), the perceived power base of the revolutionary president, Sekou Touré. Revolutionary land reform was experienced as a threat to indigenous land rights and as favoritism toward rival Manding immigrants (McGovern 2013; Højbjerg 2007). Inhabitants of the Forest Region continued to conduct their banned initiation society activities (which were legal in neighboring Sierra Leone and Liberia) in secrecy, and in fact their suppression from 1958 to 1984 had the effect of further politicizing and objectifying these practices as a unifying "religion." Consequently, from the 1990s, when restrictions on initiation societies were finally lifted, all politicians from the Forest Region, including the urban educated and "Christianized" elite, turned to the societies to rally political support (McGovern 2013; Højbjerg 2007). The result was not only a pan-Kissi, but also a pan-Forest Region, political identity (embracing those who speak Loma, Kpélé, Guerzé, Kono, and Mano). Their common historical experiences enabled the political leaders of each language area to ally and form a power bloc in modern national politics.

In short, centuries of a hostile external political order have ensured that the initiation societies that defend communities and secure their prosperity have become all the more central to political and cultural life. Neither Islam 
nor the Christian missions have easily found local converts; in 1989 religious surveys in Magenta indicated that only 7 percent of Loma people professed the Christian faith, whereas 78 percent followed traditional practices (Højbjerg 2007). ${ }^{10}$ As scholars have noted (e.g., Højbjerg 2007; McGovern 2013), it is the persistence of "cultural" practices in the Forest Region, not their demise, that seems most salient. At the same time, the Forest Region since independence has been subordinated to other regions in national politics and continues to be highly sensitive to what it perceives as a "conspiracy of power" that favors immigrant rivals and the "white" world, even over its own people and resources (its land and globally significant iron ore, gold, and diamond deposits). Initiation societies were remilitarized during the turbulent years of the Liberian and Sierra Leonean civil wars and became the locus of civil defense, with foes again being those of Manding-Islamic warring factions. Since then, episodes of sectarian violence have heightened tensions between the Forestiers and those they see as "immigrants."11

At independence, the revolutionary regime of Sekou Touré (1958-84) developed a powerful state apparatus in the central government and in the prefectures and sous-prefectures. Here, government-appointed employees represented the varied ministries (Police, Agriculture, Health, etc.) at every level. As Schroven (2010) points out, a political tradition based on colonial French practices developed, whereby these civil servants (Fonctionnaires) would not usually be natives of the region where they were employed. Those in the Forest Region are thus administered by officials associated with the regions of their historic antagonists, and they assert as well that they are discriminated against in recruitment and in nominations for administrative appointments. According to journalistic reports, "this feeling of helplessness and impunity among aggressors has revived and exacerbated communal clashes" (Guinéenews 2014).

In a democracy, an accommodation with political opponents is the norm, and yet in this region it is a highly precarious one, and several aspects of the Ebola response disrupted it. Biopolitics became political. Not only did biomedical interference with funerals undermine the loci of political power-i.e., the initiation societies-but those appointed to implement the Ebola response were "outsiders," whether Guinean or foreign. Often the Guineans employed to oversee the Ebola response were not from the locality itself but were appointed by political opponents of the local leaders. Moreover, the social and religious practices of the Forestiers are largely disdained by inhabitants of other regions of Guinea, who are mainly Muslim, as well as by Christians and politically radical African nationalists-the very outsiders appointed to positions of power at the sous-prefecture level. In other words, the very outsiders who disrespect local religious beliefs were those who oversaw the burials, displaying, according to the affected communities, a callous lack of respect for bodies, treating them like "faggots of wood" (Le Marcis 2015). In addition, as Ebola spread in the Forest Region and then beyond it, many Guineans elsewhere interpreted it as an ethnic 
disease (a disease of the Kissi or of the Forestiers) (Camara \& Lazuta 2015). The disease was thus quickly stigmatized within national ethnic stereotypes, and those who did not consider themselves susceptible to infection resented being educated to avoid it-which they interpreted as being cast as immoral. Conversely, Forestiers, too, resented being connected to Ebola and therefore cast as immoral.

Ebola contact tracing that documented friendships and traced individuals' movements was also experienced as highly intrusive political surveillance from well-resourced state officials working with an intensity hitherto unknown and in regions where state authorities usually display little interest. Concern among Guéckedou's villagers, for example, was enhanced when a forty-year-old woman (probably a leading figure in the women's initiation society), who was a known contact of a positive case and who was hospitalized in Guéckedou and showing symptoms, "escaped" in early June across the Liberian border into Lofa County. Surveillance teams tracked her down in Liberia and transferred her back to Guéckedou where she died (Fassassi 2014; Government of Liberia 2014). Such cross-border tracking had been unheard of historically.

So while one can discern a transformation in modes of state sovereignty in Guinea associated with Ebola, the response to this particular epidemic led less to the establishment of a parallel state, or of sovereignty rooted in self-surveillance (like the "republic of therapy" that emerged around HIV response in Côte d'Ivoire as documented by Nguyen 2010), and more to a reinforcement of the existing state apparatus that Forestiers perceived as oppositional.

When the medical authorities began to set up Ebola sensitization missions in villages that were as yet free of Ebola but needed to be prepared, whatever political accommodation that had existed with the outsiders broke down entirely when members of the distrusted political elite aligned themselves with the medical professionals and even used meeting styles that resembled electioneering. On September 10, 2014, the four allied opposition parties of the Forest Region (which all draw on initiation societies for their powerbase) united to object to what they saw as the politicization of Ebola sensitization and called on public vigilance (Guinéenews 2014b). A week later followed the saddest event of all when an Ebola sensitization delegation arrived at the sous-prefecture of Womey. The delegation included the governor of the Forest Region and the prefect of the prefecture, three of the most senior doctors, and several journalists. Among these was the pastor of an evangelical church that was intolerant of initiation societies and who worked for Compassion and Mercy Associates (a U.S.-based "Christ-centered relief and development agency" [The Alliance 2014]). The delegation had come to speak only of Ebola and not the wider grievances that the community wanted to address to such leaders (Guinéenews 2014a). Worse, the village had communicated that this particular day would not be suitable for hosting such a delegation as it coincided with the major "coming out" ceremony and festival for new girl initiates of the women's 
initiation society-an event that would attract senior women initiates and kin from neighboring villages.

The combination of not listening to local political expression and interfering with the initiation society proceedings proved incendiary. As the stench of bleach spray wafting overhead mixed with these other provocations, inhabitants seemed to conclude that the delegation was infecting the village. In apparent "self-defense," the women's and men's initiation societies orchestrated a preemptive attack, killing members of the delegation, blocking exit roads, and tracking down those who had escaped. They then defended their village with ex-combat machine guns until the Guinean military eventually intervened (Ouendeno 2014; Brittain 2015).

\section{The Extractive Accommodation}

A third breakdown in the accommodation between the Forest Region and Ebola-control officials had to do with matters of resource extraction. Ebola initially spread to (or proliferated in) the iron ore and diamond mining regions of the Forest Region. ${ }^{12}$ While both colonial and postcolonial governments exerted control over all deposits throughout their territory in accordance with European legislative practice, the iron, gold, and diamond deposits in Guinea have been worked historically by those in whose territory they are found, and who thus claim ancestral rights. From the landholders' perspective, others (the national political elite) have effectively "stolen" their patrimony, a sentiment all the more galling when the state sells mining rights to foreign firms. There is very little that villagers can do (as occasional resistance has been quashed by the military), so indigenous claimants must come to terms with this dispossession-an "accommodation," of sorts, but one that is at least sweetened by the promise of jobs, some community payments, and any benefits that so-called "corporate social responsibility" might bring.

Unfortunately, the Ebola epidemic coincided with a commodity price collapse. Productive iron mines were shutting down, and workers were being laid-off from other mines still in their inception phase. Ebola then precipitated further downscaling. Payments to communities were not honored and the fragile accommodation deteriorated into perceptions of planned extermination. As Guinéenews (2014b) reported, "in some areas and in remote villages, people firmly believe in the version of the introduction of Ebola by whites who have mineral resource interests, with the complicity of the government for the sole purpose of destroying their communities."

Womey, for example, is only 15 kilometers from Simandou, the world's largest untapped iron deposit and Africa's largest ever proposed mining venture. The mine has also become an iconic representation of global and Guinean corruption-the "corruption deal of the century" (Kochan 2013). Having pledged to invest just U.S.\$165 million to secure the mining rights, a company owned by an Israeli businessman, Beny Steinmetz, sold a 51 percent stake to a Brazilian company, Vale, for U.S.\$2.5 billion, and Steinmetz 
walked off with a profit of U.S.\$500 million before anything had been dug-and with the deal mired in corruption allegations (The Economist 2015; Reguly 2015). The mine had employed some three thousand locals in preparing infrastructure, but this workforce was laid off in August 2014, a month before the Womey attack (The Economist 2015) and just as the Ebola panic and expatriate flight were accentuating the iron slump. From this point, too, many villages nearer this mountain mine, including those right on its slopes such as Dondano, isolated themselves from the international Ebola response until November 2014, when levels of mortality finally rendered this untenable (Nossiter 2014b).

Scandal websites carried stories that Ebola originated from an accident in a secret biological weapons laboratory located in Kenema Hospital in Sierra Leone, funded by George Soros, a great friend and political and financial supporter of President Alpha Condé, and who was also associated with the Simandou project. News reporters in Guinea observed that Soros's NGO, the Open Society Foundation, was forced to refute the rumors and noted other stories afloat on the internet that traced Ebola to Steinmetz's revenge against the expropriation of his mining rights (Guinéenews 2014b).

Mining is not the only local wealth that has been plundered by outsiders: the region's forest reserves and protected areas attract international investment but deprive inhabitants of any benefits other than unskilled jobs. Similarly, communities in Liberia and Sierra Leone who welcomed refugees into their region during the civil wars received little, if any, compensation-whereas international organizations and state functionaries profited enormously. In June 2014, early in the epidemic, President Condé attempted to turn this resentment into political capital when he accused MSF of exaggerating the extent of the Ebola threat in order to make money.

Under less unusual circumstances, everyday practices enabling political and economic accommodation had allowed for radically different perspectives and experiences as well as major resentments over political and economic issues to pass relatively unnoticed. But just as Ebola enabled the penetration of biopolitics into funeral practices, so the imperatives of Ebola and the exceptional practices it initiated enabled these political and economic transgressions to manifest themselves clearly-not only the disrespect of the initiation societies, but also the downscaling of the workforce, the overriding of usual political protocols, the focus on the single issue of Ebola, and the distrusted procedures such as the use of chlorine spray. Only by taking this entire context into consideration can we begin to discern how relations in the Forest Region of Guinea become so fraught that citizens were capable of believing that Ebola was not only introduced by outsiders, but had been spread purposefully "to destroy them."

\section{Accommodation with Sorcery}

Local experience of the foreign, or "white," world has usually been one not of noble "humanitarianism," but of a callous selfishness that is either 
vicious or dismissive in the pursuit of accumulation. Elders in this region still recall how, during French colonization, youth from this region were forced into labor to build roads and railways, faced strict controls over mobility, and if employed in colonial plantations, also experienced apartheid and extreme inequality. Since then it remains usual, too, for young men from families living in villages across the Forest Region to travel seasonally, or for a period of years, to seek their fortunes in the artisanal gold and diamond mines in the region. They may be employed by foreign managers or otherwise work in the precarious informal mines, which are often expelled forcibly from the most productive deposits by the state when it sells concessions to foreign investors. More recently many youths have reported being subject to intense racism when attempting international migration.

This experience of structural (and actual) violence infuses local readings of "whites" and elite Africans educated in European ways. In Guinea, and as Shaw (2002) has noted, across the border in Sierra Leone, such antisocial behaviors attract suspicions of sorcery. Indeed, these relatively wealthy people usually display many characteristics of sorcerers. They lead a secluded life and do not share their gains. They exchange abrupt greetings, eat large quantities of meat, and eat alone. As Shaw discovered in Sierra Leone, "European and North American cities represent ... inaccessible urban landscapes of wealth, power, commodities, technology, mobility—and witchcraft" (2002:209).

Other anthropological literature on the region has revealed varied speculations and suspicions about the nefarious ways in which EuroAmericans (and others from around the world) acquire their wealth: how they have occult methods of identifying diamondiferous and auriferous regions; how they have "four eyes" just as indigenous "seers" do; how they have devices (sometimes described as binoculars) that help them see beyond the surface of things; how they acquire African masks to capture and harness their spirits; how they catch nature spirits, transporting them to Europe for profit, just as they have been exporting diamonds and other precious resources for decades (e.g., Diggins 2014; Diawara 1994). In short, although rarely stated, the people of the Forest Region have long coexisted with these "antisocial" intruders, but have reached an accommodation of sorts with those wielding such powers.

Throughout this region, as Jackson explains, there is an intense preoccupation with a "hidden evil in the world around you that finds dramatic expression in the clandestine activities of witches and the conspiracies of enemies" (2013:145) —an awareness of what Mariane Ferme (2001) calls the "underneath of things." Villagers envisage the existence of sorcery behind much political power and accumulated wealth-a suspicion that the formal state is something of a façade hiding occult motives and practices of elite Guineans and of those born, educated, and working abroad. It is a suspicion voiced by some critics of President Condé, who see his initiation into the esoteric secret society of Freemasonry and his intimacy with the head of MSF as confirmation of their impressions. ${ }^{13}$ 
These concerns about sorcery are not connected simply to a suspicion of white people or elite outsiders. On the contrary, many have suspicions of others within their own community and perhaps within their own familyand although they would usually not dare to confront living suspects, they may air their suspicions if suspects die. Nevertheless, there seems to be some "racial" differentiation in modes of suspicion. For example, Shaw notes that some Sierra Leoneans draw a contrast between European sorcerers who harness their powers to achieve material success and technological dominance but make their products public and visible, as opposed to African sorcerers who "keep their wonderful . . . inventions hidden, thus blocking Africa's material development” (2002:210).

We can therefore speak in terms of a fourth rupture that Ebola provoked-a rupture in this usually unchallenged coexistence with and accommodation to sorcerers. Since there is very little that most people can do about the sorcery threat, except for rooting out such evil from their own community as much as possible and working to acquire powers to discern it and protect themselves against it, the only viable strategies are rooted in wary tolerance. And again, the initiation societies are crucial in identifying and protecting against sorcerers.

There are many reasons that the Ebola phenomenon was likely to be associated with sorcery. It is a disease of the social-of those who look after and visit others, and of those who attend funerals. Those who avoid it tend to be loners who withdraw socially, do not attend funerals and other ceremonies, and are wary of touching others-all classic indicators of sorcery. Public health communications that suggested avoiding all that is socially and morally "good" thus inverted moral practice and promoted a sorcery ethic.

More specific practices on the part of the ECTs also promoted this perception. Very early in the epidemic, angry residents of Guéckedou Prefecture thought that staff at ETCs had lied to them, not only because patients were not being properly fed or looked after, but also because they thought that once a patient died "he would be deprived of his organs and of his blood" (WHO 2014c) - the signature practice of forms of sorcery that acquire power from African blood and bodies (Fairhead et al. 2007; see also White 2000). The everyday accommodation with hidden sorcery was broken as sorcerers were now, in effect, revealing themselves openly. While people sought to avoid ETCs as locations where one might become infected with Ebola, many believed that their very raison d'être was deliberate infection with tainted blood in order to hasten death (Bannister-Tyrrell 2015). Other practices of the ETCs carried all the hallmarks of overt sorcery beyond their antisocial apartheid practices, economic inequalities, barbed wire, social controls, and anonymous burials. These included the use of personal protection suits and headgear that echoed masking practices and instilled such intense fear that doctors, nurses, and burial teams quickly took to dressing in people's presence. And when Ebola teams visited villages to pick up bodies and pump in disinfectant, they also mimicked 
unwittingly the well-known traditional practices in which society leaders sprinkle decoctions. When the markets in Macenta and Nzerekore were visited by professionals clad in personal protection equipment spraying disinfectant, they attracted mob attacks.

\section{Conclusions}

This article has traced how the particularities of Ebola as a disease and the public health practices that were mobilized to address it disrupted or transgressed an array of everyday social accommodations that had developed in the Forest Region. First, the practical accommodation between hospital medicine and the cycle of life and prosperity was undermined as biomedicine (biopolitics) extended to the control of corpses and funerals. Second, the practical everyday accommodation with external political power was disrupted as, for example, Ebola led politicians external to the region to interfere with the local political machine of initiation societies. Third, the practical accommodation with extractive business interests was undermined, for example, as mines failed and ceased fulfilling their employment and revenue obligations to local communities. Fourth, the practical accommodation with evil and occult forces failed as they were rendered callously visible in the activities of ETCs and the public health response. In each case, "red lines" were transgressed.

I have taken this approach for several reasons. First, it takes as its starting point the existence of interpenetrating, multicultural worlds, rather than singular "cultures." The intention here was not to examine the Ebola debacle as a "clash of cultures," but rather to understand the ways in which the Ebola response undermined practices of "accommodation" that enable globally integrated living-practices that permit radically unequal, even "ontologically incompatible," worlds to coexist pragmatically. This approach conforms with John Dewey's philosophy of pragmatism $(1920,1929)$, in which the "search for security" and optimistic experimentalism in social life usually take priority over any "quest for certainty."14

Second, this approach therefore enables us to see how histories of structural violence are latent within these everyday accommodations and cooperation. It also enables us, third, to see how transgressive actions that disrupt these accommodations involve specific people and power relations and thus need to be studied situationally. Things did not unfold in the same way everywhere. Fear and violent resistance were common, but they were not ubiquitous. This approach therefore enables us to appreciate how resistance varied-how different "red lines" were crossed in different locations and also over time, as the epidemic unfolded. While this article has focused on the Kissi-speaking world in Guinea and in the Forest Region, the same analysis could also be applied to other regions such as Forecariah, where resistance was associated with the breakdown in accommodations with Islamic burials, with political opposition, and with other iron ore mines. This work has also focused only on events early in the epidemic-largely 
between April 2014 and November 2014. Both communities and the public health response altered their practices with time.

Fourth, the transgressive situations documented here evoked emotive responses to the perceived immorality and improprieties that were strong enough to cause flight, resistance, and murder. If any "cultural" differences can be discerned, they become apparent in these transgressive acts. Indeed, this analytic approach finds evidences of "culture" and cultural symmetry in transgressive social processes and the act of blocking. Such symmetry, however, is an aberrant state. As Whyte (1997) observes (following Dewey), this pragmatic approach foregrounds local moral worlds. It embraces analysis not simply of a world of ideas, but also of moral values and communal goals. And yet by the same token, as I have argued here, in taking a pragmatic approach we need to be attentive to its limits- to the limits of communal tolerance. Putting one's foot down-blocking-reveals the limits of pragmatism. What we see as culture is rendered visible when pragmatism hits moral limits. Culture has only a negative, fleeting manifestation.

This approach, therefore, allows us to see better why any attempt to "de-exoticize" responses to Ebola through an appeal to a universal common sense obscures the history of structural violence-its very real social legacyand the explosive but latent tensions that are present in modes of everyday accommodation. Appeals to universals may enable us to believe ourselves to be empathetic, and to create universalist grounds for respect, but the cost is neglect of the radical differences (in experience and interpretation) that accommodations conceal. The village where Melissa Leach and I lived was kind enough to allocate a "minder" to help us to navigate our lives in the village, but also to steer us away from accidentally probing issues that were considered secret. We may have had wealth, but our sense was that villagers rather pitied outsiders like ourselves who could not be initiated into the men's and women's Toma society, and who would never understand-would never be allowed to understand-the deeper mysteries of this world and the parallel worlds of the dead-mysteries and rituals that are crucial to securing health, protection, fertility, and social solidarity (see Richards et al. 2015a). Acknowledging such difference is also a basis of respect.

That Ebola disrupted the social accommodations was due to the particularities of the disease. Ebola was exceptional (1) in requiring patient isolation and biomedicalized burial; (2) in spreading through morally "good" practices; (3) in being deadly enough to turn the political rivalry with which it was entangled into questions of life and death; and (4) in being such a global security threat that it attracted a massive international response that was economically and politically functional to those controlling patrimonial politics.

Ebola control had been the subject of resistance in Congo and Uganda in very similar circumstances, and the problematic tendency of "crisis management" to rupture respectful communication has also been well documented (e.g., Hewlett \& Hewlett 1996; Gasquet-Blanchard 2015). Within a month of Ebola's being identified in Guinea, anthropologists familiar with 
the social dynamics precipitated by the humanitarian response to earlier Ebola outbreaks in central West Africa had been recruited by WHO to advise on the response in Guinea. Julienne Anoko and Alain Epelboin, for example, outlined how ETCs could circumvent social isolation by creating a welcoming ECU design, enabling families to cook for patients, supplying mobile phones to communicate with those in isolation, treating suspicions seriously, enabling highly respectful burials (including sacrifices and ritual engagements with families of the dead), linking up with local healers and men's and women's religious authorities, and creating media programs that would show respect to these local figures and give them air time (Anoko 2014b). Yet such advice went largely unheeded (Le Marcis 2015). When "culture" was considered in the development of safe and dignified burial guidelines, it acknowledged only Christian and Islamic traditions (WHO 2014a). This article points to the significance of wider practices in epidemic response that should have addressed (and have been seen to address), rather than reinforce, local experiences of political, economic, and cultural inequality. These practices should have extended to matters of staff recruitment and types of financial support. In the longer term, policies addressing such inequalities will facilitate global epidemic response in the future.

During the Ebola crisis, local concerns about ETCs, mine owners, politicians, and sorcerers all surfaced, but were mostly dismissed by humanitarians and journalists as "rumors," with those who "believed them" portrayed as credulous and in need of "education" or correction via public health messaging. ${ }^{15}$ I hope to have shown here how the expression of such stories can be linked not just to the structural violence in the region's history, but also to the systemic accommodations that were being broken and the structural violence latent within them.

\section{Acknowledgments}

This article emerged from a rapidly produced draft that I circulated as the Ebola epidemic escalated in October 2014, and from a redraft in February 2015 that addressed the then continuing social resistance to the Ebola response in Guinea. I am most grateful to Julienne Anoko for sharing the reports of her extraordinary work addressing resistance in Guinea, and to members on the Ebola Response Anthropology Platform and their debates on the place of "culture" in Ebola response. I have also had the good fortune to be able to develop my analysis with insights from participants at several events: the panel titled "Anthropological Engagements with the Ebola Epidemic in West Africa” convened by Annie Wilkinson as part of the EASA conference, "Anthropology and Global Health: Interrogating Theory, Policy and Practice," University of Sussex, U.K., September 9-11, 2015; and the conference "Beyond Ebola: Knowledge Production and the Limitations of Translation" organized by Anita Schroven and Rose Marie Beck, October 28-30, 2015, at the Max Planck Institute for Social Anthropology at Halle, Germany. I would particularly like to thank the comments there of Adia Benton and Chris 
Hann, who I hope will see the productivity of their critique. A revised draft was presented at the American Anthropological Association conference (Denver, Colorado). I thank Richard Rottenburg, Sharon Abramowitz, and Anita Schroven for their extremely insightful comments. Finally I must thank Ella Kusnetz for the insights that emerged from such diligent copy editing. Errors of fact or interpretation are, of course, my own.

\section{References}

Abramowitz, Sharon, et al. 2014. "The Opposite of Denial: Social Learning at the Onset of the Ebola Emergency in Liberia." http://www.ebola-anthropology.net.

Abramowitz, Sharon, and Pat Omidian. 2014. "Brief on Attitudes Towards EbolaRelated Funerary Practices and Memorialization in Urban Liberia.” http:// www.academia.edu.

ACAPS. 2015. "Ebola in West Africa-Guinea: Resistance to the Ebola Response." http://www.alnap.org.

The Alliance. 2014. "Alliance Ebola Team Member Killed in Guinea." September 18. https://www.cmalliance.org.

Anoko, Julienne. 2014a. "Communication with Rebellious Communities during an Outbreak of Ebola Virus Disease in Guinea: An Anthropological Approach.” http://www.ebola-anthropology.net.

— 2014b. "Humanisation de la réponse à la Fièvre Hémorragique Ebola en Guinée: une approche anthropologique." Powerpoint presentation, Conakry, April 2014.

—. 2014c. "La réparation de la malédiction générale suite à l'enterrement d'une femme enceinte avec le bébé dans le ventre: Une approche anthropologique pendant l'épidémie de la Maladie à Virus Ebola en Guinée." https://f.hypotheses.org.

Azuine, R. E., et al. 2015. "Ebola Virus Disease Epidemic: What Can the World Learn and Not Learn from West Africa?" International Journal of MCH and AIDS 3 (1): $1-6$.

Bannister-Tyrrell, Melanie, et al. 2015. "Blood as Medicine: Social Meanings of Blood and the Success of Ebola Trials." The Lancet 385 (9966): 420.

Benton, Adia, and Kim Yi Dionne. 2015. "International Political Economy and the 2014 West African Ebola Outbreak.” African Studies Review 58 (1): 223-36.

Brightman, Robert. 1995. "Forget Culture: Replacement, Transcendence, Relexification." Cultural Anthropology 10 (4): 509-46.

Brittain, Amy. 2015. "The Fear of Ebola Led to Slayings-And a Whole Village Was Punished." Washington Post, February 28. http:/ / www.washingtonpost.com.

Camara, Zakaria, and Jennifer Lazuta. 2015. "One Year On: Why Ebola Is Not Yet Over in Guinea.” IRIN, March 23. www.irinnews.org.

Carrithers, Michael, et al. 2010. "Ontology Is Just Another Word for Culture." Critique of Anthropology 30 (2): 152-200.

Chandler, Clare, et al., for the Ebola Response Anthropology Platform. 2015. "Ebola: Limitations of Correcting Misinformation." The Lancet 385: 1275-76.

Claver, Yves. 2014. "Macenta-Koyama: Des violences contre Ebola causent des dégâts dans la localité." August 13. www.Guinéeplus.net.

Dewey, John. 1920. Reconstruction in Philosophy. New York: H. Holt \& Co.

-1929. Experience and Nature. London: Allen and Unwin. 
Diawara, Mamodou. 1994. "Der Blick vom anderen Ufer. Oder: Die Entdeckung des Weißen.” In Europa, aber was ist es? Aspekte seiner Identität in interdisziplinärer Sicht, edited by Joerg A. Schlumberg and Peter Segl, 255-83. Köln: Böhlau.

Diggins, Jennifer. 2014. "Slippery Fish, Material Words: The Substance of Subsistence in Coastal Sierra Leone.” Ph.D. diss., University of Sussex.

Dionne, Kim Yi, and Laura Seay. 2015. "Perceptions about Ebola in America: Othering and the Role of Knowledge about Africa." PS: Political Science Eै Politics 48 (1): 6-7.

The Economist. 2014. "Crying Foul in Guinea." December 6. http://www.economist. com.

Epelboin, A., et al. 2008. "Humanisations et consentements éclairés des personnes et des populations lors des réponses aux épidémies de FHV en Afrique centrale (2003-2008) in Mesures de contrôle des infections et droite individuels: Un dilemme étique pour le personnel médical.” Humanitarian Stakes 1 (September).

Fairhead, James, and Melissa Leach. 1994. "Contested Forests: Modern Conservation and Historical Land Use in Guinea's Ziama Reserve." African Affairs 93: 481-512.

-1996. Misreading the African Landscape: Society and Ecology in a Forest-Savanna Mosaic. Cambridge, U.K.: Cambridge University Press.

Fairhead, James, Melissa Leach, and Mary Small. 2006. "Where Technoscience Meets Poverty: Medical Research and the Economy of Blood in The Gambia, West Africa." Social Science and Medicine 63: 1109-20.

Fairhead, James, et al. 2003. African American Exploration in West Africa. Bloomington: Indiana University Press.

Farmer, Paul. 2004. "An Anthropology of Structural Violence.” Current Anthropology 45: 305-17.

Fassassi, Amzath. 2014. "How Anthropologists Help Medics Fight Ebola in Guinea." September 24. http:/ / www.scidev.net.

Faye, Sylvain. 2015. "L'“exceptionnalité' d'Ebola et les 'réticences' populaires en Guinée-Conakry: Réflexions à partir d'une approche d'anthropologie symétrique." Anthropologie Ẽ Santé 11 https:/ / anthropologiesante.revues.org.

Ferme, Mariane. 2001. The Underneath of Things: Violence, History and the Everyday in Sierra Leone. Berkeley: University of California Press.

Fribault, Mathieu. 2015. "Ebola en Guinée: Violences historiques et régimes de doute." Anthropologie Ẽ Santé 11. https:/ /anthropologiesante.revues.org.

Gasquet-Blanchard, Celia. 2015. "Ebola, géographie d'un virus: Enjeux sociospatiaux en Afrique Centrale Perspectives pour l'Afrique de l'Ouest. "L'espace politique 26 (2). http:/ / espacepolitique.revues.org.

Graeber, David. 2015. "Radical Alterity Is Just Another Way of Saying 'Reality': A Reply to Eduardo Viveiros de Castro.” Hau 5 (2).

Government of Liberia. 2014. "Ebola Virus Disease Epidemic in Liberia Situation Report, 6 June 2014." http:/ / reliefweb.int.

GuinéeConakry.info. 2014. "N'Zerekore: Révolte populaire contre les 'auteurs' d'Ebola." August 29. http:/ / www.guinéeconakry.info.

Guinéenews. 2014a. "Ebola et la poudrière de la Guinée Forestière. Part 1.” http:// Guinéenews.org.

—. 2014b. "Poudrière Forestière: La part d'erreurs de sensibilisation dans le drame de Womey (2ème Partie).” http:/ / Guinéenews.org.

Hewlett, Barry, and Bonnie Hewlett. 2008. Ebola, Culture and Politics: The Anthropology of Emerging Disease. Belmont, Calif.: Thomson. 
Højbjerg, Christian Kordt. 2007. Resisting State Iconoclasm among the Loma of Guinea. Durham, N.C.: Carolina Academic Press.

Iffono, Aly Gilbert. 2010. Le peuple Kissi (Guinée, Liberia, Sierra Leone) face aux colonisations. Paris: l'Harmattan.

—. 2011. Naître, viure et mourir en pays kisi précolonial: Essai d'anthropologie en pays kisi precolonial. Essai d'anthropologie sociale et culturelle. Paris: L'Harmattan.

International Committee of the Red Cross (ICRC). 2015. "Red Cross Red Crescent Denounces Continued Violence against Volunteers Working to Stop the Spread of Ebola." February 12. www.ifrc.org.

Jackson, Michael. 2013. Lifeworlds: Essays in Existential Anthropology. Chicago: University of Chicago Press.

Jehovah's Witnesses. n.d. "Why Don't Jehovah's Witnesses Accept Blood Transfusions?" https://www.jw.org.

Kochan, Nick. 2013. "The Corruption Deal of the Century: How Guinea Lost Billions of Pounds in Simandou Mining Licensing." The Independent, June 17. www.independent.co.uk.

Leach, Melissa, and Annie Wilkinson. 2014. "Briefing: Ebola Myths, Realities, and Structural Violence.” African Affairs 114 (454): 138-48.

Leach, Melissa, et al. 2008. "New Therapeutic Landscapes in Africa: Parental Categories and Practices in Seeking Infant Health in Republic of Guinea." Social Science and Medicine 66 (10): 2157-67.

Le Marcis, Frédéic. 2015. “Traiter les corps comme des fagots' Production sociale de l'indifférence en contexte Ebola (Guinée)." Anthropologie Ẽ Santé 11. https:/ /anthropologiesante.revues.org.

Loudah, Bah Boubacar. 2014. "Départ du Gouvernement: Le ministre Makanéra répond à Jean Marie Doré.” AfricaGuinée, October 14. http:/ /www.africaGuinée. com.

McEwan, Ian. 2014. The Children's Act. London: Jonathan Cape.

McGovern, Michael. 2013. Unmasking The State: Making Guinea Modern. Chicago: University of Chicago Press.

Momou, Guilana. 2015. "Ebola: Le movement Croix-Rouge inquiet des violences contre ses volontaires in Guinée." Guinéenews, February 12. http://Guinéenews. org.

Nguyen, Vihn-Kim. 2010. Republic of Therapy: Triage and Sovereignty in West Africa's Time of AIDS. Durham, N.C.: Duke University Press.

Nossiter, Adam. 2014a. "Fear of Ebola Breeds a Terror of Physicians." New York Times, July 27.

— 2014b. "Fear of Ebola Opens Wary Villagers to Outsiders in Guinea." New York Times, November 16.

L'Obs. 2014. "Ebola: la Guinée appelle au calme après une attaque contre MSF." April 5. http://tempsreel.nouvelobs.com.

Ouendeno, Marie. 2014. "Rapport de la mission dans la sous-préfecture de Womey, Préfecture de N'Zérékoré du 15 septembre 2014.”

Pas, Remco van de. 2015. "On Politics and the Ebola Pathogen: Why Does Community Resistance Persist in Guinea?” http:/ / www.internationalhealthpolicies.org.

Paulme, Denise. 1946. "La notion de sacrifice chez un peuple 'fétichiste' (les Kissi de la Guinée française)." Revue de l'histoire des religions 1946 (132): 48-66.

—. 1950. "Fautes sexuelles et 'premiers morts' dans une société africaine." Journal de Psychologie 1950 (4): 507-24.

-1954. Les Gens du riz. Paris: Librarie Plon. 
Reguly, Eric. 2015. "Wealth of Iron Ore in Guinea's Simandou Buried by Corruption Politics." The Globe and Mail. October 2. http://www.theglobeandmail.com.

Richards, Paul. 2016. "A Matter of Grave Concern? Charles Jedrej’s Work on Mende Sodalities, and the Ebola Crisis." Critical African Studies 8 (1): 80-91.

Richards, Paul, et al. 2015a. "Village Responses to Ebola Virus Disease in Rural Central Sierra Leone: An Interim Report to the SMAC Program, DfID Freetown." January 12. www.ebola-anthropology.net.

— 2015b. "Social Pathways for Ebola Virus Disease in Rural Sierra Leone, and Some Implications for Containment.” PLOS Neglected Tropical Diseases. blogs.plos.org.

Rottenburg, Richard, et al. 2015. The World of Indicators: The Making of Governmental Knowledge through Quantification. Cambridge, U.K.: Cambridge University Press.

Schroven, Anita. 2010. "The People, the Power and the Public Service: Political Identification during Guinea's General Strikes in 2007.” Development and Change 41 (4): 659-77.

Shaw, Rosalind. 2002. Memories of the Slave Trade: Ritual and Historical Imagination in Sierra Leone. Chicago: University of Chicago Press.

White, Louise. 2000. Speaking with Vampires: Rumour and History in Colonial Africa. Berkeley: University of California Press.

Whyte, Susan Reynolds. 1997. Questioning Misfortune: The Pragmatics of Uncertainty in Eastern Uganda. Cambridge, U.K.: Cambridge University Press.

World Health Organization (WHO). 2014a. "How to Conduct Safe and Dignified Burial of a Patient Who Has Died from Suspected or Confirmed Ebola Virus Disease." www.who.int.

. 2014b. "Sierra Leone: A Traditional Healer and a Funeral." www.who.int. . 2014c. "Wise People' Help to Fight Ebola in Remote Villages of Guinea." www.who.int.

\section{Notes}

1. Abramowitz et al. (2014) and Abramowitz and Omidian (2014) provide grounded evidence of the extent of cooperation in Liberia.

2. See also Dionne and Seay (2015).

3. Azuine et al. (2015) and Leach and Wilkinson (2014) also outline the failure in public health, and along with Fribault (2015), Faye (2015), and GasquetBlanchard (2015), among others, they highlight the significance of structural violence in shaping acts of resistance.

4. Rosalind Shaw (2002) has argued that the pervasive fear of capricious wandering spirits and of duplicitous sorcerers in the community are actually an effect of (a "memory" of) the slave trade and of subsequent exactions: of structural violence. These fears, she argues, emerged in response to slave raiders and a social world where villages were eventually apt to "sell their own." The arts of concealment and secrecy, she continues, are also responses to slavery, pointing out that preslavery accounts describe long vanished shrines to more neighborly and helpful spirits who protected people from specific diseases and the like. The emerging importance of secret men's initiation societies in the nineteenth century for establishing regional and panethnic political alliances, "slave-free zones," and trade monopolies, and for providing military security, support this 
argument (Fairhead et al. 2003). In Guinea's Forest Region, however, these memories extend to fears not only of capricious spirits and ancestors, but also to enduring concerns about the capricious "white" and Muslim worlds.

5. The idea of pursing a "symmetrical anthropology" out of frustration with the focus on "local culture," as outlined by Faye (2015), and an attempt to balance this focus with attention to "humanitarian culture" does not really overcome this problem, as it leaves the totalizing concept implicit.

6. I allude here to debates about culture in the 1990s (e.g., Brightman 1995) or its more recent manifestation in debates over perspectivism (e.g., Carrithers et al. 2010; Graeber 2015).

7. As Richards (2016) outlines, initiation societies (sodalities) themselves improvise, accommodating to new challenges.

8. The continued performance of burial rites despite advice and regulation was widely documented throughout the region (see, e.g., Richards et al. 2015b).

9. I use the term "white" as a translation from the regional Tubab (tubabu), which refers to an outsider whose difference from locals is immediately apparent, and usually predicated on skin color, therefore referring to those of Euro-American, or more recently Asian, origin. Contextually, however, it can refer a person of African American origin, or indeed to a West African whose dress, comportment, or other material signature is symbolically "other."

10. Most Christians as well usually accommodate initiation society rites. The 15 percent who are practicing Muslims are essentially Loma's Manding ethnic rivals living in the region.

11. A military coup in 2008 did install a Forestier, Moussa Dadis Camara, as president. He is a Guerze speaker from Lola Prefecture and he drew on initiation societies to build ethnic militias. His political ascendency, however, was short lived and murderous. Internal opposition was supported by the "white" international community, and he was deposed in 2009 after an assassination attempt.

12. It eventually spread as well to the iron ore regions of the Forecariah-Sierra Leone borderlands and the bauxite mining regions north at Boke, which are beyond the scope of this article.

13. The magazine Jeune Afrique called the president's Masonic connections to the attention of Guineans in 2011 and 2013. The specific concern with Freemasonry in the uniting of Islamic and Christian powers punctuated comments of opposition websites that cast Alpha Condé as murderous (e.g., "Abedi," in Mamou 2015). On MSF and Alpha Condé, see Pas (2015).

14. My thanks to Richard Rottenburg for making this connection. See Rottenburg (2015) and also Whyte (1997) for anthropological analyses that draw on Dewey in this way.

15. See Chandler et al. (2015) for further critique. 